\title{
Integrated Land Registration System: Between Legal Certainty and Challenges (Case of Semarang City)
}

Published by Faculty of Law Universitas Negeri Semarang. The Journal has been accredited by Ministry of Research \& Technology (SINTA 3). () Author(s). This work is licensed under a Creative Commons Attribution-NonCommercial-ShareAlike 4.0 International License.

Fairus Augustina Rachmawati ${ }^{1} \bowtie$, Shafa Amalia Choirinnisa ${ }^{2}$, Latif Latif 3

1,2 Faculty of Law, Universitas Negeri Semarang, Indonesia

${ }^{3}$ National Land Agency, Semarang, Indonesia

Corresponding author: fairusagustinarachmawati@students.unnes.ac.id

Abstract: In providing legal certainty for the control and ownership of community land parcels, the government carries out a program of registration and data collection of land parcels or what is called Complete Systematic Land Registration (PTSL). In its implementation, the city government of Semarang is targeting as many as 50,000 certificates to be registered with a total of 55,000 land parcels so that with a high quantity output, many problems will occur and a strategy is needed to solve it. Based on these problems, it is necessary to study related problems and the completion of the Semarang City PTSL Program 2021. The research was carried out using a juridical approach by obtaining the results of research in the field. Especially in the area of Bendan Duwur and Sampangan urban villages, Semarang City in implementing the PTSL program in 2021 in the City of Semarang. Through this research, the obstacles to implementing PTSL Semarang City 2021 lie in the implementation of socialization, data collection and asset registration as well as in digitizing PTSL data. The settlement strategy that can be taken to minimize the problems of implementing PTSL is by improving resource strategies, coordinating with villages / sub-districts in making a Physical Land Acquisition Statement, as well as educating the public regarding online data that has been undertaken to support conversion from analog data to data. digital.

Keywords: Land Registration, Legal Certainty, Integrated Land Registration

\section{How to cite:}

Rachmawati, F., Choirinnisa, S. A., \& Latif, L. (2021). Integrated Land Registration System: Between Legal Certainty and Challenges (Case of Semarang City). Indonesian Journal of Advocacy and Legal Services, 3(2), 217-232. https://doi.org/10.15294/ijals.v3i2.45895 


\section{A. Introduction}

Land registration is a very important thing for all people in Indonesia to provide legal certainty to obtain legal protection for the control and ownership of a land parcel. Legal certainty guarantees that are to be realized are in the form of rights ownership status, certainty of the subject of rights, and also certainty of the object of land rights. The existence of legal certainty over land rights is the aim of managing the Medium-Term Development plan.

The implementation of land registration is the obligation of the government and rights holders as stipulated in Law No. 5/1960 Articles 19, 23, 32 and 38. The implementation of the first land registration is Complete Systematic Land Registration (PTSL) organized by the ministry through ATR / BPN. PTSL is a land registration activity for the first time carried out for all land parcels by collecting and determining the truth between the physical data and the juridical data of the land. with the aim of realizing the provision of legal certainty and legal protection of community land rights based on the principles of simple, fast, smooth, safe, fair, even, open and accountable. So that it can improve welfare and prosperity for the community.

The PTSL program is carried out evenly throughout all regions in Indonesia, including in the city of Semarang. The Semarang City ATR / BPN targets more than 55,000 parcels registered, 50,000 land parcels that have been certified, and also 148,000 plots for data improvement or K4 with the aim of becoming a Complete City. The legal umbrella for the PTSL Program refers to the Regulation of the Minister of ATR / KA BPN No. 6 of 2018 regarding Complete Systematic Land Registration (PTSL).

The implementation of PTSL is carried out by registering land parcels, both certified and uncertified, by involving RT, RW, LPMK, BABINSA, subdistrict, and National Land Agency which will then produce output in the form of a land list or nominative for each sub-district. Then in its implementation, namely by collecting physical data / measurements of land parcels and also collecting juridical data. Which will later be collected through the Kelurahan, so that it becomes a complete ward.

A series of implementation of the PTSL program has been carried out starting from pre-socialization for each sub-district, to socialization at the Kelurahan level. Of course this is done so that the public knows about the purpose of the Complete Systematic Land Registration program in the City of Semarang. Although various regulations in implementing PTSL have been carried out. However, there are still obstacles in the implementation of PTSL in 2021. Various problems regarding the PTSL program still occur in the 
community which cause obstruction to the implementation of PTSL in an area.

Therefore, in this paper we want to examine the problems and negative and positive impacts of this PTSL program, as well as provide efforts or forms of resolution to problems in the 2021 Complete Systematic Land Registration in Semarang City.

\section{B. Method}

This study uses an empirical juridical approach. The approach in this research is carried out based on the main legal material by examining theories, concepts, principles, and laws and regulations related to this research. Where we review the legal provisions that apply in society and identify what is happening in people's lives. In this juridical approach we analyze the Regulation of the Minister of ATR / BPN Number 6 of 2018 concerning Complete Systematic Land Registration.

The type of data used in this paper is primary data, we obtained this primary data from the results of research in the field. Especially in the area of Bendan Nduwur and Sampangan urban villages, Semarang City in implementing the PTSL program in 2021 in the City of Semarang. In addition, we also use secondary data that we get from online legal sources, both from laws, ministerial regulations, and other regulations. After the data for the study had been obtained, we conducted an analysis of the problems that occurred in the 2021 Complete Systematic Land Registration (PTSL) program in Semarang City.

\section{Result and Discussion}

1. The Problems of the PTSL Program in Semarang City 2021

The PTSL 2021 program in Semarang City is a breath of fresh air for people who are waiting for a clearer legal status of their land rights. Therefore, various kinds of facilities are applied for the smooth running of this program. However, in implementing this PTSL program, there are various macroblematics, namely:

1) Socialization / Outreach

The government, in making a public policy, is always followed by socialization. This is a process that is carried out after the policy is made and before the policy is implemented. ${ }^{1}$ In implementing this policy,

\footnotetext{
1 Dian Herdiana, (2018), "Sosialisasi Kebijakan Publik: Pengertian dan Konsep Dasar".
} Jurnal Ilmiah Wawasan Insan Akademik, 1(3), p. 17. 
socialization plays an important role so that the policy can be implemented perfectly, here are the reasons:

a. The substance of public policy needs to be known by various parties.

In this case, socialization is an effective way of disseminating information about public policies to be implemented.

b. The parties who are targeted and related to the policies made need knowledge and understanding of these public policies. Therefore, socialization is present as a bridge to provide guidance, knowledge and understanding to the target and related parties. After the public policy is made, of course there needs to be a response, readiness and the ability of the parties involved. Therefore, socialization has a role to provide an overview and prediction of the success rate of the implementation of these public policies.

In implementing the PTSL program in 2021 in the city of Semarang, the Land Office as the party implementing the program conducted outreach to the target or related parties, this socialization was held in January-March. The parties who received the socialization were the community and government instruments from RT to District as well as related parties. In addition, Muspika elements are also involved which will support the smooth running of the PTSL program in 2021 in the city of Semarang.

Matters that are conveyed in the socialization or counseling are contained in Article 16 paragraph (2) Battle of the Minister of Agrarian and Spatial Planning / Head of the National Land Agency Number 6 of 2018 concerning Complete Systematic Land Registration which reads: ${ }^{2}$

(2) Extension as referred to in paragraph (1) shall be conducted by providing an explanation at least regarding:

a. benefits for the community, government and the State for the results of implementing PTSL activities;

b. stages and mechanisms of PTSL activities;

c. determination and installation of brick signs for each plot of land;

d. juridical documents that need to be prepared;

e. schedule for measuring land parcels and collecting juridical data by the Physical Task Force and the Juridical Task Force;

f. the final result of PTSL activities;

2 Pasal 16 ayat (2) Petaruran Menteri Agraria dan Tata Ruang/ Kepala Badan Pertanahan Nasional Nomor 6 Tahun 2018 tentang Pendaftaran Tanah Sistematis Lengkap 
g. financing provided by the Government and / or other legitimate sources through PTSL activities;

h. legal consequences that occur if the obligations and responsibilities referred to in letters $\mathrm{c}$ and $\mathrm{d}$ above are not fulfilled;

i. the right to object to the adjudication results announced during the announcement period; and

j. fees and / or taxes that will be borne by PTSL activity participants."

The Land Office as the responsible party, of course, already has its own strategy in order to socialize the PTSL program. This is evidenced by the conduct of PTSL Pre-socialization and PTSL Socialization. A total of 16 Districts and 177 Kelurahan must have received this socialization. Therefore, it is not uncommon for the socialization of related parties to be carried out in rotation from one sub-district to another and within a day the Semarang City Land Office can provide outreach to several areas. This lack of personnel resulted in a lack of in-depth socialization. Socialization carried out for related RT and RW which will later become an extension of the hand in order to provide understanding to the community, there is often miscommunication.

This matter, impact on public perceptions of this PTSL program which is considered a certificate bleaching program. In fact, these two things are different programs. In addition, it is not uncommon for people to flock to the Land Office directly to inquire or even provide necessary documents that should be collected collectively through the RT and RW of the kelurahan. This indicates that the socialization carried out to RT and RW is not in depth. Due to limited time and personnel owned by the Semarang City Land Office. It is not uncommon for people to flock to the Land Office directly to inquire or even provide necessary documents that should be collected collectively through RT and RW kelurahan.

This indicates that the socialization carried out to RT and RW is not in depth. Due to limited time and personnel owned by the Semarang City Land Office. It is not uncommon for people to flock to the Land Office directly to inquire or even provide necessary documents that should be collected collectively through RT and RW kelurahan. This indicates that the socialization carried out to RT and RW is not in depth. Due to limited time and personnel owned by the Semarang City Land Office.

In addition, the characteristic of urban society is the individual characteristic of society which is caused by an environment that is competitive and has a high degree of heterogeneity in various 
aspects. ${ }^{3}$ This characteristic is also a factor in hindering the socialization process because many people do not care about the activities being held in the community. And as a result, many people do not know in-depth and comprehensive information about PTSL in 2021 in the city of Semarang.

\section{2) Data collection and asset registration}

One of the goals of holding the PTSL program is that all land parcels in the city of Semarang are registered and have certificates, including assets belonging to agencies in the city of Semarang. These agencies are: Regional Military Command IV Diponegoro; Polrestabes of Semarang City; PT. KAI Daop IV Semarang; Regional Financial and Asset Management Agency (BPKAD) Central Java Province; Regional Financial and Asset Management Agency (BPKAD) Semarang City; PT. Rajawali Nusantara Indonesia; PT. Perhutani Central Java Regional Division; PT. Pelindo III (Persero) Regional Central Java; The Pemali River Basin Hall - Juana; PT. PLN (Persero) Central Java; Supervision and Customs Service Office Type Madya Pabean A Semarang; BRI Regional Office Semarang; BTN Semarang Regional Office; Bank Mandiri Semarang Regional Office; Central Java Bank Semarang Regional Office. About 17 of these agencies have assets that are scattered throughout the city of Semarang.

Plots of land belonging to the agency must be recorded and registered, so that all assets are recorded and can be properly utilized. However, it is also not uncommon to collect data and register these assets. There are many obstacles, such as agencies that legally own these assets (have proof of ownership or reasons for this) but do not physically control them. On the other hand, there are parties who control the land physically but do not have proof of ownership or legal title.

Of course, this has an impact on both parties who do not get clear legal certainty. Because each party does not control physically or juridically. Of course, this dispute must be resolved first in order to move up to the next stage. Because in accordance with Article 12 paragraph (1) Government Regulation Number 24 of 1997 concerning Land Registration which reads: 4

"The land registration activities for the first time include:

a. physical data collection and processing;

3 Saebani, Beni Ahmas, (2017), "Sosiologi Perkotaan: Memahami Masyarakat Kota dan Problmematikanya", Bandung: Pustaka Setia, p. 26.

4 Pasal 12 ayat (1) PeraturanPemerintahNomor 24 Tahun 1997 tentangPendaftaran Tanah 
b. proof of rights and bookkeeping;

c. certificate issuance;

d. presentation of physical data and juridical data;

e. storage of public registers and documents."

This indicates that proof of rights is very important during the land registration process. In addition, the result of the dispute between these parties has hampered the running of the PTSL program for the affected communities and agencies. The related agencies cannot collect data and manage their assets and the community is threatened that they cannot get land to live in. Even though in reality, the community has been occupying the land for more than 20 years. However, this does not mean that the relevant agency has waived rights.

\section{3) Data digitization}

The National Land Agency has a visionary view, this is marked by various kinds of easy services and fast-paced, digital-based access to information. Transformation and renewal have continued to be developed since 2013. There are land services that can now be accessed electronically, including: Insured Rights; Land Value Zone Information (ZNT); Certificate of Land Registration (SKPT); and the last is checking the certificate of land. ${ }^{5}$

To support the conversion from analog data to digital data, it is necessary to have steps that must be passed. In this PTSL program at the same time converting analog data into digital. like the example. Data collection and measurement is still carried out on land that has been certified to validate existing data in the previous system. The incoming data is then processed and can be accessed electronically.

For the first time land registration, a soft file is required. This has led to many obstacles in its implementation. Many ordinary people still don't understand how to scan and enter data into Excel. Moreover, many RT heads and RW heads are not very good at operating this matter. So, there are often miscommunications related to what data needs to be digitized and which ones don't.

Moreover, recently there has been news about the digital certificate discourse. The public is worried that the data they have is misused or even transferred through this digital system. This resulted in some

5 Kementerian Agraria dan Tata Ruang/Badan Pertanahan Nasional 11/2020, diakses dari

https://www.atrbpn.go.id/?menu=baca\&kd=ggRcUci0mPyDw8H5J+rp5RyCDy+HrbjScc $\mathrm{vG}+$ VrdonSALT1Ik6uD7EBxWh+mOAXp>. [diakses pada 20 Maret 2021] 
parties refusing to submit their data to support data digitization services carried out by the Semarang City Land Office. This is also still related to the news or hoaxes spreading among the public.

\section{The Impact of Implementation of PTSL 2021 in Semarang City}

Land titling is a step that must be taken by all castes of society, both ordinary people and state officials and even the president, to obtain a right base that has legal certainty to own a parcel of land, namely a certificate. Registering land is something that is indispensable in the context of land management. Registering land in the ATR / BPN database will facilitate and improve services in the land sector. ${ }^{6}$

In implementing the Complete Systematic Land Registration (PTSL) program, it has received many positive responses from various circles of society and also helps the community to obtain legal certainty. The PTSL program is a program that is simultaneously implemented for all regions in the Republic of Indonesia. As has been explained that PTSL uses the 3M factor, namely Spread, Thorough, Evenly. This program is from BPN through one door, namely from the Kelurahan or something equivalent. Therefore, it requires accurate and fast communication and information distribution in the dissemination of all matters concerning the PTSL program such as mapping, data collection, both physical and juridical, data validation,

The following are the impacts that are likely to occur in the implementation of PTSL 2021 in the City of Semarang with a sample of the Bendan Duwur and Sampangan Villages: Impact does not mean things that are always associated with negative, impact is an effect that appears or appears after something is carried out or implemented. Various positive impacts were also obtained by the PTSL 2021 participant community, in addition to getting convenience and making it free by the government for all its management they will also get legal certainty or land rights, along with the positive impacts of PTSL 2021 on the community and BPN:

1) Obtaining Certainty of Rights

As we know, land registration is an activity carried out by the government in order to provide legal certainty for the community regarding their land ownership. Land registration is also a mandate of Article 19 of Law Number 5 of 1960 concerning Basic Agrarian Principles, which has been stated in Article 19 paragraph (1) of the UUPA that "To ensure legal certainty by the government, land registration is held 6 Wahyuni, "Problematika Pelaksanaan Pendaftaran Sistematik Lengkap Dan Alternatif
Penyelesaianya", Sekola Tinggi Pertanahan Nasional, p. 2. 
throughout the territory of the Republic of Indonesia. according to the provisions regulated by the Government Regulation".7

Complete Systematic Land Registration in 2021, which distinguishes it from the previous year, one of which is that the certificate is given with the information that BPHTB and PPH are owed, so the certificate will be given and BPHTB and PPH can be paid afterwards. If last year must attach BPHTB and PPH paid off. Because this is stated in PP No. 24/1997 where if there is a transfer of land rights, the obligation given to the parties concerned is to attach proof of payment of fees for acquisition of land and building rights (BPHTB and PPh) The government in 2021 provides relief by granting certificates with payable BPHTB and $\mathrm{PPH}$, but the public is obliged to fulfill their obligations after the certificate is issued or thereafter. ${ }^{8}$

With the registration of land and the issuance of a certificate from the PTSL program, people who previously had not registered their land will get certain legal certainty. Where the title or certificate has been registered with BPN and the receipt is in the form of a certificate in the name of the owner of the land or building concerned. By registering the land into the data at BPN, legally the land owner has legally owned the land.

\section{2) Reduction of Disputed Land}

Described in the Regulation of the Minister of Agrarian and Spatial Planning / Head of the National Land Agency of the Republic of Indonesia Number 11 of 2016 concerning Settlement of Land Cases, it has been explained that: "Land Disputes, hereinafter referred to as Disputes, are land disputes between individuals, legal entities, or institutions that have a wide impact" . Land disputes usually have occurred because of several factors, namely the perpetrators of buying and selling land against the law (especially land) in effect in Indonesia, the two land certification

Ridho Afrianedy, "Kepastian Hukum Bagi Tanah Adat Setelah Adanya Undang-Undang Nomor 5 Tahun 1960 Tentang Peraturan Dasar Pokok-Pokok Agraria", diakses dari https://www.pa-cilegon.go.id/artikel/251-kepastian-hukum-bagi-tanah-adat-setelahadanya-undang-undang-nomor-5-tahun-1960-tentang-peraturan-dasar-pokokpokokagraria\#: :text=Pendaftaran\%20tanah\%20merupakan\%20amanat\%20dari, wilay ah\%20Republik\%20Indonesia\%20menurut\%20ketentuan\%2D , pada Maret 192021.

8 Isdana Ayu, (2019), "Kepastian Hukum Penguasaan Tanah Melalui Pendaftaran Tanah Sistematis Lengkap Di Kota Batu”, Jurnal Mimbar Hukum, 31(3), p. 347. 
systems in Indonesia are merely formalities. Therefore, the land dispute court system can generate a lot of money and a lot of time. ${ }^{9}$

With the existence of PTSL, land certification becomes easier and if all fields have been recorded by BPN and have also been certified, the possibility of disputes will be less. Disputes usually originate from the unclear reasons for the existing rights in a land parcel, and then some people begin to admit that the land is theirs, with many claims on the land then a dispute occurs. With the existence of this PTSL, land parcels that have not been certified and do not have a definite title will be given a certificate which in addition to providing strong legal certainty for the land owner also avoids disputes with other people.

\section{3) Land Value Increases}

The Sales Value of Tax Objects (NJOP) is a barometer or one of the factors that refers to determining the price of a building or land. Several studies have proven the dynamics of the selling value of land and also the factors that can influence it in Indonesia. Hadi has conducted research on making research models regarding the determination of the Tax Object Sales Value (NJOP) by paying attention to the spatial location and physical factors of the land on the land studied in Jakarta. The land factors that have been studied include CBD, land area, road width, and front width. From this research, it has been shown that the land area, road width and front width have a very positive effect on the selling price of land in the study area, but CBD has a negative effect.10

Yenna, Hermanto and Bambang have also conducted research in Sukoharjo District where land prices in the area have increased twofold after land certification. This result is evident where the price of land in the area is Rp. 57,076.92 per $\mathrm{m} 2$, and after being certified the average in the area is IDR $125,653.85$ per $\mathrm{m} 2 .{ }^{11}$ With this research, land certification has been proven to increase the selling price or value of the land. The NJOP will change after the registered object has a certificate because the land already has a title. With this, in my opinion, residents will also be greatly helped apart from obtaining legal certainty, the price of the land

\footnotetext{
9 Yuhan Al Khairi, "Sengketa Tanah - Definisi , Hukum dan Cara menyelesaikannya", dikutip darihttps://www.99.co/id/panduan/sengketa-tanah, pada tanggal 19 Maret 2021.

10 Yenna, Hermanto et all, (2016), "Pengaruh Sertifikasi Tanah Terhadap Nilai Tanah Dan Kondisi Ekonomi Masyarakat Di Kabupaten Sukoharjo", Jurnal Aplikasi Bisnis dan Manajemen , 2(3), p. 307. 
they own will increase over time, because land is a very valuable asset and the price is sure to increase every year.

Likewise in Semarang, especially in the sample areas in the making of this journal, namely Bendan Nduwur Village and Sampangan Village. The people there are very enthusiastic about participating in the PTSL program, apart from expecting a certain right base with the existence of PTSL the land they own is expected to increase in value after obtaining a certificate. In Kelurahan Sampangan and Bendan Nduwur according to the data that I saw and asked the community, namely in the Sampangan Village area, I had time to ask one of the residents what the price of land in the area was even though I had not seen the NJOP, he said that per meter it could be up to $4-5$ million rupiah. This is very beneficial if uncertified land gets a certificate, its value will soar.

\section{4) Easier Land Data Collection}

PTSL or Complete Systematic Land Registration in addition to having a land registration function also has a function for data collection, BPN conducts land data collection on all land, both certified and uncertified. According to BPN data for Semarang City, from an area of 378.67 Km2, 16 Districts and 177 Kelurahan there are 627,120 land parcels and 558,613 (89.08\%) registered land plots, 418,004 (74.83\%) mapped, unmapped $(140,609) \quad(25.83 \%)$, and $68,507 \quad(10.92 \%)$ unregistered land parcels. ${ }^{12}$ With the existence of PTSL through the data collection function of all land parcels in the city of Semarang, it is hoped that it will be recorded and recorded in the BPN system.

This data collection is carried out starting from the data collection of land parcels, both registered (certified) and unregistered (not certified) by involving RT, RW, LPMK, BABINSA, BHABINKAMTIBNAS, Kelurahan, BPN. The output is a list of land / nominative lists per village. After that carry out physical data collection / measurement and juridical data collection which is carried out by focus per sub-district, after which one sub-district has finished it will shift to the next sub-district and so on (either community land or assets owned by the government) so that it is expected that the data in each Kelurahan to be complete, complete District and City complete (3M, Close, Close, Comprehensive).

With the data collection of land assets in the form of Fasum / FASOS / RTH / river roads etc., starting from the RT / RW / Kel, Kec to Semarang City levels are recorded and registered so that related to location,

12 Paparan Sosialisasi PTSL 2021 BPN Kota Semarang 
maintenance, submission of repair proposals etc., the supporting data will be clearer. Each land can have a PBB NOP "Addres" and an integrated Population NIK, so that each land parcel is identified who owns it and knows the PBB tax data, so that the potential for PAD in Semarang City will be better.

\section{Resolving Obstacles to Implementing the PTSL Program in Semarang City 2021}

In the implementation of the Complete Systematic Land Registration program in the City of Semarang, especially those that have been undertaken in Bendan Duwur and Sampangan sub-districts, of course there are various obstacles in the implementation of PTSL 2021. Basically, the purpose of holding the PTSL 2021 program is one of which is to provide legal certainty and legal protection to community related to the control of a land parcel, especially the holder of land rights based on the principles of simple, fast, smooth, safe, equitable and open and accountable. Legal certainty can be in the form of issuance of proof of ownership of land rights originating from land registration activities in the form of issuance of proof of ownership to prove himself as the holder of the rights concerned. ${ }^{13}$

The various problems and constraints that occur in the implementation of Complete Systematic Land Registration in Semarang City, of course, must be able to solve the problem, here are the solutions that can be used as a solution to the problem of PTSL Semarang City according to the author, namely as follows:

\section{1) Improving the Strategy of Resources, Facilities and Infrastructure}

The completion of the complete systematic land registration program is through improved strategies in coordination carried out by the PTSL core committee in Semarang City. Coordination is needed with the concept of mutual benefit, it is necessary to formulate what benefits are obtained, the coordination system is also not only local but more national in nature so that it does not depend on the quality of everyone's communication skills. ${ }^{14}$

Complete Systematic Land Registration will not run successfully if it is not supported by other institutions / sectors. Support from the local government is also very important and needed because in terms of

13 Mira Novana Ardani, (2019), Tantangan Pelaksanaan Kegiatan Pendaftaran Tanah Sistematis Lengkap dalam Rangka Mewujudkan Pemberian Kepastian Hukum, Jurnal Gema Keadilan. 6(3), p. 270. Hlm 270.

14 Wahyuni, (2017), Problematika Pelaksanaan Pendaftaran Sistematik Lengkap dan Alternatif Penyelesaiannya (Studi Kasus di Provinsi Sumatera Utara), Sekolah Tinggi Pertanahan Nasional, p. 3. 
completeness of the PTSL files issued by other agencies. ${ }^{15}$ In this case, the coordination improvement strategy carried out by the Village Government will benefit the availability of village maps for the purposes of planning and implementing village development.

In addition to the coordination that needs to be improved, which is an important concern in the implementation of PTSL 2021, namely in Human Resources in the implementation of PTSL 2021 because the need for human resources greatly determines the success of implementing PTSL in terms of quality and quantity. The insufficient number of human resources in the Semarang City Land Office is coupled with the problem of routine land registration services which is quite large, the number of land parcels increases every year in PTSL activities. Of course, it is necessary to calculate the number of ASN with the volume of work, so that routine work and PTSL can go hand in hand without neglecting routine activities. ${ }^{16}$ So, according to the author, in implementing the PTSL program by increasing the number of available human resources and in terms of quality of resources, it will be a solution to the problem of implementing PTSL in the city of Semarang. In addition, efforts need to be made in overcoming obstacles in the implementation of PTSL by the Semarang City Land Office related to the volume of acceptance of routine activities / routine land services that receive routine work every day in addition to completing work related to PS.

\section{2) Proof of Ownership of Rights}

In the second settlement, there is evidence of ownership of rights which has been regulated in Article 22 of the Ministerial Regulation / Head of BPN No. 6 of 2018 which explains that in the case of incomplete or non-existent land ownership, it can be completed and proven by a written statement regarding the physical ownership and / or control of the land in good faith by the person concerned. ${ }^{17}$ The statement letter must also be witnessed by at least 2 (two) witnesses from the local environment who are not blood-related or have no family ties. The elucidation contained in article 22 requires a written statement regarding physical control over land parcels in good faith.

$15 \quad$ Ibid, p. 14.

16 Dian Aries Mujiburohman, (2018), "Potensi Permasalahan Pendaftaran Tanah Sistematik Lengkap (PTSL)", Jurnal Bhumi Sekolah Tinggi Pertanahan Nasional. 4(1), p. 93.

17 Peraturan Menteri/Ka.BPN No. 6 Tahun 2018 tentang Pendaftaran Tanah Sistematis Lengkap 
To minimize the occurrence of land dispute cases, the importance of the role and coordination of the village / kelurahan is not neglected in making a Statement of Physical Land Acquisition as formal evidence of control over land in good faith, there must be recognition and justification by the customary law community or the village / kelurahan concerned. Furthermore, the element of good faith from the fact that physically controls, uses, utilizes, and maintains the land from generation to generation for a certain period of time and / or obtains in a way that does not violate the provisions of laws and regulations. Good faith is evidenced by the statement of the PTSL Adjudication applicant / participant stating that there are no objections from other parties regarding land that is owned or not in a state of dispute and is not included or is not an asset of the Government, Regional Government, ${ }^{18}$ Basically, good faith means honesty, honesty of rights holders in acquiring land, honesty in fulfilling predetermined conditions.

3) Public Education Related to Electronic Digitalization Technology

The development of technology is currently very fast, everything is completely digital. In this digital era, humans generally have a new lifestyle that cannot be separated from all electronic devices. Technology can be a tool that can help most human needs. Technology can be used by humans to make it easier to do any task and job. The important role of technology is what brings human civilization into the digital era. ${ }^{19}$ So that in an effort to resolve obstacles in the PTSL 2021 program, the role of the government in the implementation of the Semarang City PTSL program is to educate the public regarding online data that is currently being undertaken to support the conversion from analog data to digital data, there are steps that must be passed. In this PTSL program at the same time converting analog data into digital. The incoming data is then processed and can be accessed electronically. For the first time land registration, a soft file is required.

So that ordinary people who still do not understand how to scan and enter data into excel prior to the implementation of the PTSL program, the socialization is explained regarding how to scan data and what is prioritized in the committee also needs young people who understand more about technology because many RT and RW heads are not so adept

18 Pasal 22 peraturan Menteri/Ka.BPN No. 6 Tahun 2018 tentang Pendaftaran Tanah Sistematis Lengkap

19 Wawan Setiawan, (2017), "Era Digital dan Tantangannya. Seminar Nasional Pendidikan" p.1. 
at operating it. So, there are often miscommunications related to what data needs to be digitized and which ones don't.

\section{Conclusion}

Various regulations have been made to run the PTSL program in order to provide guarantees and legal certainty as well as provide legal protection to reduce disputes. However, in its implementation there are still obstacles. The problems arise from pre-socialization, socialization, to the implementation of this PTSL. resolution and efforts to obstruct the implementation of PTSL Semarang City 2021, namely improving the strategy for resources, facilities and infrastructure, the importance of the role and coordination of villages / sub-districts not being neglected in making a Statement of Physical Mastery of Land as formal evidence of control over land in good faith must be recognized and justified by the customary law community or the village concerned.

\section{E. Acknowledgments}

None.

\section{F. Declaration of Conflicting Interests}

The authors states that there is no conflict of interest in the publication of this article.

\section{G. Funding}

None.

\section{H. References}

Afrianedy. R, "Kepastian Hukum Bagi Tanah Adat Setelah Adanya UndangUndang Nomor 5 Tahun 1960 Tentang Peraturan Dasar Pokok-Pokok Agraria”, accessed on https://www.pa-cilegon.go.id/artikel/251kepastian-hukum-bagi-tanah-adat-setelah-adanya-undang-undangnomor-5-tahun-1960-tentang-peraturan-dasar-pokokpokokagraria\#: :text=Pendaftaran\%20tanah\%20merupakan\%20aman at\%20dari,wilayah\%20Republik\%20Indonesia\%20menurut\%20ketentu an\%2D , accessed on March 192021.

Ahmas, S. B. (2017), "Sosiologi Perkotaan: Memahami Masyarakat Kota dan Problmematikanya", Bandung: Pustaka Setia. 
Ardani, M. N. (2019), Tantangan Pelaksanaan Kegiatan Pendaftaran Tanah Sistematis Lengkap dalam Rangka Mewujudkan Pemberian Kepastian Hukum, Jurnal Gema Keadilan. 6(3).

Ayu, I. (2019), "Kepastian Hukum Penguasaan Tanah Melalui Pendaftaran Tanah Sistematis Lengkap Di Kota Batu", Jurnal Mimbar Hukum , 31(3).

Herdiana, D. (2018), "Sosialisasi Kebijakan Publik: Pengertian dan Konsep Dasar". Jurnal Ilmiah Wawasan Insan Akademik, 1(3).

Kementerian Agraria dan Tata Ruang/Badan Pertanahan Nasional 11/2020, accessed

https://www.atrbpn.go.id/?menu=baca\&kd=ggRcUci0mPyDw8H5J+rp5 $\mathrm{RyCDy}+\mathrm{HrbjSccvG}+$ VrdonSALT1Ik6uD7EBxWh+mOAXp>. in March 20th 2021.

Khairi, Y. A. "Sengketa Tanah - Definisi , Hukum dan Cara menyelesaikannya", dikutip dari https://www.99.co/id/panduan/sengketa-tanah, accessed on March 19th 2021.

Mujiburohman, D. A. (2018), "Potensi Permasalahan Pendaftaran Tanah Sistematik Lengkap (PTSL)”, Jurnal Bhumi Sekolah Tinggi Pertanahan Nasional. 4(1).

Paparan Sosialisasi PTSL 2021 BPN Kota Semarang

Peraturan Menteri Agraria dan Tata Ruang/ Kepala Badan Pertanahan Nasional Nomor 6 Tahun 2018 tentang Pendaftaran Tanah Sistematis Lengkap

Peraturan Pemerintah Nomor 24 Tahun 1997 tentangPendaftaran Tanah

Setiawan, W. (2017), "Era Digital dan Tantangannya. Seminar Nasional Pendidikan"

Wahyuni, (2017), Problematika Pelaksanaan Pendaftaran Sistematik Lengkap dan Alternatif Penyelesaiannya (Studi Kasus di Provinsi Sumatera Utara), Sekolah Tinggi Pertanahan Nasional.

Yenna, Hermanto et all, (2016), "Pengaruh Sertifikasi Tanah Terhadap Nilai Tanah Dan Kondisi Ekonomi Masyarakat Di Kabupaten Sukoharjo", Jurnal Aplikasi Bisnis dan Manajemen , 2(3). 